\title{
Increased mortality, delayed hatching, development aberrations and reduced activity in brown trout (Salmo trutta) exposed to phenethyl isothiocyanate
}

Asa B. White ${ }^{1}$, Angelo P. Pernetta ${ }^{1}$, Chris B. Joyce ${ }^{2}$, Neil Crooks ${ }^{1}$

${ }^{I}$ Centre for Aquatic Environments, School of Pharmacy and Biomolecular Sciences, University of Brighton, Huxley Building, Lewes Road, Brighton, U.K.

${ }^{2}$ Centre for Aquatic Environments, School of Environment and Technology, University of Brighton, Cockcroft Building, Lewes Road, Brighton, BN2 4GJ

Correspondence: Asa White, School of Pharmacy and Biomolecular Sciences, University of Brighton, Huxley Building, Lewes Road, Brighton, U.K.

Email: whitediatom@gmail.com

Keywords

PEITC, Watercress, Biofumigation, Chalk stream

\section{Acknowledgements}

This study was financially supported by The Vitacress Conservation Trust and a University of Brighton PhD Studentship. We would also like to thank Allenbrook Trout Farm, Dorset and The Berkshire Trout Farm, Berkshire, for the supply of Salmo trutta gametes that were used in this study. 


\begin{abstract}
Plants of the order Brassicaceae have evolved a chemical defence against herbivory; the glucosinolate-myrosinase system. Mechanical damage to plant tissues, such as grazing, initiates the production of phenethyl isothiocyanate (PEITC), a compound toxic to invertebrates. Mechanical damage caused during biofumigation and the harvesting and washing of watercress presents routes for PEITC release into waterbodies, such as the chalk stream spawning sites of brown trout (Salmo trutta). This laboratory study exposed developing S. trutta embryos to PEITC at concentrations of 0.01, 0.1 and $1 \mu \mathrm{g} / \mathrm{L}$. S. trutta exposed to $1 \mu \mathrm{g} / \mathrm{L}$ PEITC during embryonic development resulted in $100 \%$ mortality after 4 dose days. Exposure to $0.1 \mu \mathrm{g} / \mathrm{L}$ PEITC resulted in an approximate fourfold increase in mortality relative to the controls, while exposure to $0.01 \mu \mathrm{g} / \mathrm{L}$ PEITC had a negligible effect on embryo mortality. Embryos exposed to $0.1 \mu \mathrm{g} / \mathrm{L}$ PEITC showed a significant delay in hatching and produced alevins with significantly shorter total lengths, lighter body weights and an approximate threefold increase in spinal deformities relative to those exposed to the controls and 0.01 $\mu \mathrm{g} / \mathrm{L}$ PEITC. The results of a motor activity assay demonstrate that alevins exposed to PEITC showed a significant decrease in swimming activity compared to control animals during periods of illumination. The increased mortality, teratogenic effects and impaired behaviour in S. trutta following embryonic exposure to relatively low concentrations of PEITC highlights a need to accurately quantify and monitor environmental levels of PEITC.
\end{abstract}

\title{
1. Introduction
}

Phenethyl isothiocyanate (PEITC) is a secondary metabolite produced by brassicas in response to herbivory (Fenwick et al., 1983). Mechanical damage of the plant tissues brings the enzyme myrosinase into contact with glucosinolates stored within cell vacuoles, hydrolysing the glucosinolates into PEITC (Halkier and Gershenzon 2006). There is a large and growing body of evidence indicating that PEITC may reduce the risk of carcinogenesis and heart disease when consumed by humans (Traka and Mithen 2009; Dinkova-Kostova and Kostov 2012; Abbaoui et al. 2018; Pan et al. 2018), which has led to vegetables rich in PEITC, such as watercress, being described 
as superfoods (Rodrigues et al. 2016). While consumption of PEITC is potentially beneficial to humans, it has well-documented allelopathic and genotoxic properties (Shelton 2005). To a range of aquatic and terrestrial invertebrates it is a chemical deterrent to consumption (Newman et al. 1990, 1996; Kerfoot et al. 1998), and an environmental toxicant (Dixon and Shaw 2011; Ntalli et al. 2017).

The shift from pollution-sensitive to pollution-tolerant macroinvertebrate taxa immediately downstream of watercress farm discharges are considered in part to have resulted from potential large scale discharges of PEITC from the watercress industry (Roddie et al. 1992; Cox 2009; Mainstone 1999). In 2009, 39 registered watercress farms were in operation in the UK, totalling over 52.6 hectares of cress beds, all of which were irrigated using abstracted spring water (Cox 2009). These farms are typically situated at the headwaters of chalk streams, where effluent water from the cress beds can be discharged. The harvesting of watercress and maintenance of cress beds result in mechanical damage to the crop so are thought to release PEITC into effluent water (Cox 2009; Dixon and Shaw 2011). On a small number of farms, the effluent from the washing of watercress and other imported salad leaves is also discharged into the receiving chalk stream. These salad washing processes are likely to contribute a more significant and chronic load of PEITC, as in contrast to intermittent harvesting, salad washing occurs daily. In November 2007, a producer on the Bourne Rivulet, Hampshire, re-routed salad wash water through cress beds prior to discharge to dilute PEITC and provide greater time for its breakdown. Consequently, the number of Gammarus shrimp and pollution-sensitive macroinvertebrate taxa downstream of the discharge increased (Dixon 2010).

The increasing demand for organic produce has led to a large and growing body of research into the use of non-synthetic pest control practices such as biofumigation (Matthiessen and Kirkegaard 2006; Gimsing and Kirkegaard 2009; Ntalli et al. 2017). Biofumigation involves the maceration of brassicas - activating the glucosinolate-myrosinase system - which are then incorporated into soils. A range of isothiocyantes, including PEITC, are produced, to control soilborne pathogens, nematodes and weeds (Petersen et al. 2001; Smith and Kirkegaard 2002; Rumberger and Marschner 2003). Laboratory trials showed that following biofumigation, isothiocyanates may be washed down into soil to a depth of $1 \mathrm{~m}$ during a heavy rainstorm (Laegdsmand et al. 2007). The study estimated leachate 
from soil could enter waterbodies located close to fields where applications took place at PEITC concentrations of up to $50 \mu \mathrm{g} / \mathrm{L}$.

The environmental concentrations of PEITC released from the harvesting of watercress and salad washing have not been accurately quantified. Two separate studies have estimated PEITC concentrations in discharge water from a watercress farm in Hampshire, England. Worgan and Tyrell (2005) calculated an estimate of the PEITC released from the harvesting of watercress as 320-590 $\mu \mathrm{g} / \mathrm{L}$ over a 24 hour period. Dixon (2010) estimated there to be between 600-1040 $\mu \mathrm{g} / \mathrm{L}$ PEITC in salad wash effluent. Quantification of environmental levels of isothiocyanates is challenging due to their volatility and reactivity (Chen and Ho, 1998; Doheny-Adams et al. 2018). In an aqueous matrix, the degradation of PEITC is $\mathrm{pH}$ and temperature-dependent. Higher temperatures have been shown to cause more rapid degradation of PEITC, and at $\mathrm{pH} 7.4$ PEITC had a half-life of 56 hrs at $25^{\circ} \mathrm{C}$ and $108 \mathrm{hrs}$ at $4^{\circ} \mathrm{C}$ (Ji et al. 2005). Assuming a linear relationship between temperature and PEITC halflife, at an average chalk stream aquifer water temperature of $11^{\circ} \mathrm{C}$, PEITC may have a half-life of up to 90 hours.

An indigenous salmonid of Europe, North Africa and Western Asia, brown trout Salmo trutta are an ecologically and commercially important species in chalk streams (Elliott 1989; Klemetsen et al. 2003). S. trutta spawning occurs in late December/early January in the United Kingdom, when females bury eggs fertilised by males in gravel nests or redds (Mann et al. 1989). The embryos develop in the darkness of the gravels over winter, until hatching into a larval stage (alevins). Alevins carry a ventral yolk sac which is consumed while remaining in the safety of the gravel nest. The alevins swim up once most of the yolk has been consumed, emerging from the gravel as fry in early spring (Crisp 1993). The incubation period and time of emergence ranges from one month to several months, with cooler water temperatures lengthening the process (Elliott and Hurley 1998; Klemetsen et al. 2003). Prior to emergence from the redd, alevins are photonegative (Bams 1969). This photonegative response is considered a survival instinct to return them to the safety of the gravel following disturbance of the redd through, for example, scour (Fast and Stober 1984). The early life stages of $S$. trutta are especially sensitive to xenobiotics (Finn 2007; Power 1994), where the large 
size of $S$. trutta eggs ( $>5 \mathrm{~mm}$ ), and the long developmental period may favour increased uptake of toxicants during the incubation period (Kristensen 1994; Schubert et al. 2014).

Watercress is traditionally harvested from September to April (Cox, 2009), coinciding with the spawning, incubation and hatching of salmonids. Moreover, as watercress farms are typically located on chalk stream headwaters, which are favoured spawning sites, salmonid embryos face a potential risk of exposure to PEITC. Consequently, this study was designed to experimentally determine the impacts of PEITC exposure on embryonic S. trutta by exposing developing embryos to a logarithmic dosing regime and comparing mortality and hatch rates, teratogenic effects and behavioural responses to light exposure with control treatments.

\section{Methods}

\subsection{Animals}

The methodology and use of $S$. trutta embryos were reviewed and approved by the University of Brighton's Animal Welfare \& Ethical Review Body (AWERB). Due to the life stages involved in the experiment (pre-independent feeding), the procedure did not enter the regulatory framework of the Animals (Scientific Procedures) Act 1986 Amendment regulations (SI 2012/3039) and experiment time-frames were designed around this (Strähle et al. 2012).

S. trutta gametes were sourced from Allenbrook Trout Farm, Dorset, UK (trial one) and The Berkshire Trout Farm, Berkshire, UK (trials two and three). Eggs from two females and milt from a single male were obtained and the gametes transported in a cool box to the laboratory. Eggs were fertilised in tap water which had been matured by aerating for at least 24 hours to remove chlorine and cooled to $10^{\circ} \mathrm{C}$.

\subsection{PEITC stock solution preparation}

A stock solution was created using reagent grade (99\%) PEITC (Sigma-Aldrich, Darmstadt, Germany) added to matured tap water. Dimethyl sulfoxide (DMSO) was chosen as a solvent for its relatively low toxicity to fish at levels of $1 \% \mathrm{v} / \mathrm{v}$ or lower with hatch rate, morphological development and survival as endpoints (Hallare et al. 2006; Maes et al. 2012). PEITC was added to DMSO (78.13 
$\mathrm{g} / \mathrm{mol}$ ) (Sigma-Aldrich, Darmstadt, Germany) over an increasing range of ratios, with the resultant assay observed under a stereo microscope for persistence of oil droplets. PEITC was fully dissolved at a ratio of $1 \mu \mathrm{g}$ PEITC in $1000 \mu 1 \mathrm{DMSO}$, therefore stock solutions of 1:1000 PEITC/DMSO were used throughout.

\subsection{Preliminary trial}

A pilot study was carried out on rainbow trout (Oncorhynchus mykiss) in order to determine the sublethal dose of PEITC. Treatments consisted of a water control, a solvent control and three daily dosed PEITC treatments at $0.5,1$ and $2 \mu \mathrm{g} / \mathrm{L}$. Embryo mortality in all PEITC treatments reached $100 \%$ by 14 days past fertilisation (dpf). These results informed the lower dosing regimen for the subsequent $S$. trutta trials.

\subsection{Embryo rearing}

The system comprised a series of three $30 \times 30 \times 30 \mathrm{~cm}$ aquaria each containing five aerated $400 \mathrm{ml}$ glass beakers suspended through a polystyrene tile. A square of Parafilm ${ }^{\circledR}$ (Bemis, NA, USA) was placed over the top of each beaker to minimise water loss and prevent dust and airborne pathogens entering the beakers. Water quality analysis was carried out daily on randomly selected beakers within each of the three aquaria. Dissolved oxygen $(\mathrm{DO} \mathrm{mg} / \mathrm{L})$ and temperature $\left({ }^{\circ} \mathrm{C}\right)$ were measured using a Hanna H19142 probe (Hanna, USA), and pH was measured with a Hanna HI98107 pocket pH tester (Hanna, USA). Three independent trials were conducted, with the following water parameters maintained; trial one: temperature $\left(10.52 \pm 0.30^{\circ} \mathrm{C}\right)$, dissolved oxygen $(11.1 \pm 0.50 \mathrm{mg} / \mathrm{L})$ and $\mathrm{pH}$ (7.81 \pm 0.19$)$. Trial two: temperature $\left(11.32 \pm 0.19^{\circ} \mathrm{C}\right)$, dissolved oxygen $(9.24 \pm 0.42 \mathrm{mg} / \mathrm{L})$ and $\mathrm{pH}$ $(8.17 \pm 0.15)$. Trial three: temperature $\left(11.06 \pm 0.20^{\circ} \mathrm{C}\right)$, dissolved oxygen $(9.56 \pm 0.27)$ and $\mathrm{pH}$ $(8.19 \pm 0.12)$.

\subsection{PEITC dosing regimen and incubation maintenance}

Of the three trials, trial one was a developmental phase following the preliminary trial to confirm lethal and sublethal concentrations of PEITC for S. trutta. For trial one, only data pertaining to mortality rates and incidents of spinal abnormalities were included as no other morphometric or 
behavioural trials were carried out for these alevins. Only in trials two and three are length, weight, and behavioural data analysed.

Each treatment was carried out in triplicate with 50 fertilized $S$. trutta embryos in each replicate. Embryos were exposed to PEITC treatments of $0.01,0.1$ and $1 \mu \mathrm{g} / \mathrm{L}$, water controls and solvent controls. The solvent control was set at $1 \mathrm{ml} / \mathrm{L}$ to replicate DMSO concentrations in the $1 \mu \mathrm{g} / \mathrm{L}$ treatment in trial one, but subsequently lowered to $100 \mu \mathrm{g} / \mathrm{L}$ to replicate the $0.1 \mu \mathrm{g} / \mathrm{L}$ PEITC treatment for trials two and three after it became apparent that $1 \mu \mathrm{g} / \mathrm{L}$ PEITC treatment would result in total mortality before the trial terminated.

The beakers were randomly allocated within the rearing system, where the embryos were acclimatised for $24 \mathrm{hrs}$ prior to the first dosing of PEITC. Each replicate beaker was maintained with $250 \mathrm{ml}$ of matured tap water in a $24 \mathrm{hr}$ dark photoperiod throughout the trial. Daily $80 \%$ water changes were performed by syphoning off $200 \mathrm{ml}$ from each beaker. They were then topped back up with $200 \mathrm{ml}$ of matured tap water or matured tap water containing PEITC/DMSO stock. The desired concentration was created $25 \%$ stronger than the target concentration in each beaker to allow for dilution in the $50 \mathrm{ml}$ of water remaining in each beaker. The first PEITC dosing was performed at $1 \mathrm{dpf}$ and was repeated every third day for the duration of the trials until the hatching of the first alevin, whereupon dosing was ceased. Every 24 hours the embryos were checked for hatches and mortality, with dead embryos removed to prevent fouling of the water.

During trials two and three newly hatched alevins were removed daily from each treatment at $\leq 1$ day post hatch (dph) and euthanised in 2-phenoxyethanol until the day there were at least 24 hatched alevins per treatment, at which point these were set aside and allowed to develop for four days (trial two) and two days (trial three) for the motor activity assay. Subsequent hatches were euthanised daily at $\leq 1 \mathrm{dph}$. Euthanised alevins were fixed in $4 \%$ formalin prior to morphological analysis. 


\subsection{Motor activity assay}

Activity levels under light and dark conditions were investigated using a motor activity assay in a DanioVision $^{\mathrm{TM}}$ chamber (Noldus, Wageningen, Netherlands). This closed system consisted of an infrared Basler acA1300-60 GenICam camera (Basler AG, Ahrensburg, Germany) fitted above a chamber which tracked movements of alevins placed in a 6-well microtiter plate. Water at $11^{\circ} \mathrm{C}$ was circulated underneath the plate to maintain temperature in the wells (arenas). From each treatment, 24 alevins were randomly selected and transferred into individual arenas using a plastic $3 \mathrm{ml}$ pipette, prepared by cutting off the narrowed tip. Each 6-well plate contained alevins from the same treatment, with the order of trial randomised. Each arena was filled with $10 \mathrm{ml}$ of water taken from their respective housing beakers. The trials were conducted in a dimmed room, with the alevins transfered rapidly into the DanioVision ${ }^{\mathrm{TM}}$ behaviour chamber to minimise light exposure. The alevins were first allowed to acclimatise for 4 minutes in darkness prior to recording a 10 minute cycle of 2 minutes of dark/light/dark/light/dark. The cycle times were set at 2 minutes, similar to the studies by Hua et al. (2014) and Bossus et al. (2014). At the onset of monitoring, the position of fish were recorded every $0.04 \mathrm{~s}$ using EthoVision XT V11 software (Noldus, Wageningen, Netherlands) with the software recording the activity in terms of velocity $(\mathrm{cm} / \mathrm{s})$, distance moved $(\mathrm{mm})$, duration of movement (s) and duration of inactivity (s) of each subject.

\section{7 Motor activity analysis}

The measurements of activity produced the same trends during all trials of the present study, so just one endpoint has been chosen for analysis and reporting: the distance moved (mm) per unit time. For each treatment, the distance moved by all alevins of each treatment between each $0.04 \mathrm{~s}$ frame was averaged. These averages were subsequently averaged into $10 \mathrm{~s}$ time bins for analysis of overall activity levels during the trial and activity levels in light and dark conditions. The data for each $10 \mathrm{~s}$ bin summarised the distanced moved over the preceding $10 \mathrm{~s}$. The data from two arenas were removed as outliers prior to analysis, one from the $0.01 \mu \mathrm{g} / \mathrm{L}$ PEITC treatment and one from the water control. In both instances, the software had not tracked the alevin in the arena correctly resulting in exceptionally high readings. 


\section{8 Morphometrics}

Morphometric analysis for each treatment was carried out on the 24 alevins used in the motor activity assay at $4 \mathrm{dph}$ in trial two, and $2 \mathrm{dph}$ trial three. In addition, 30 randomly selected alevins from the day of peak hatch (the day that $>50 \%$ hatched) and all subsequent later hatches for trials two and three were used. For trial one, 24 randomly selected alevins per treatment were used to record incidences of spinal deformities. Alevins were selected randomly by combining replicates into one beaker, which was gently swirled and poured through a hand net until the desired number of alevins were counted out. The preserved specimens were rinsed in fresh water to remove formalin and the yolk was dissected from the body and blotted dry of all moisture. The body, including the membrane surrounding the yolk, and the yolk itself were then separately weighed to four decimal places on a Sartorius AZ124 analytical balance (Germany). The alevins were photographed laterally and dorsally using a 16.3 MP Fujifilm x70 camera (Fujifilm, Tokyo). Photography was performed after the removal of the yolk sac, allowing the alevins to lie flat to increase accuracy of image analysis.

All image analysis was undertaken in ImageJ (https://imagej.nih.gov/ij/), with length measurements in $\mathrm{mm}$ to three decimal places. Total length was taken as a standard measurement, running from the tip of the snout to the end of the caudal fin following the lateral line. In instances of scoliosis, total length was either measured from the dorsal image, or by flattening the alevin down with forceps during photographing. Instances of lordosis (excessive inward curvature), kyphosis (excessive outward curvature), scoliosis (abnormal lateral curvature) or 'stump body' (a strong anterior-posterior compression of the vertebrae (see Tave et al. 1982)) were recorded as presence or absence following visual identification (Fig 1). Lastly, any animal displaying any one or combination of the aforementioned spinal abnormalities was recorded as displaying vertebral column disorder (VCD).

\subsection{Statistics}

Normality was tested using the Shapiro-Wilk test, and homogeneity of variance evaluated using the Levene test. Where data were normally distributed and exhibited homogenous variance a one-way ANOVA was performed, followed by Tukey's post-hoc test. In converse cases, data were analysed using the Kruskal-Wallis test, with significant differences in medians explored using pair-wise Mann- 
Whitney tests. There was no significant difference between the solvent control and water control for the majority of endpoints so, following OECD protocol (OECD 1992; Green and Wheeler 2013), the data for both controls were pooled to increase statistical power. As recommended in the OECD protocol, in cases where there was a significant difference between the controls, the solvent control only was used in the analysis. The motor activity assay data were analysed with Repeated Measures ANOVA with individuals set as a random factor and treatment and condition as set as fixed factors. Post-hoc comparisons used the Bonferroni method. All statistical analysis was performed using Minitab 18 (Minitab, Inc, USA) with significance set at $p<0.05$.

\section{Results}

\subsection{Embryo Mortality}

Exposure during embryonic development to the highest PEITC concentration $(1 \mu \mathrm{g} / \mathrm{L})$ resulted in $100 \%$ mortality in all three trials. Rapid mortality commenced following the third PEITC dose at 7 dpf, resulting in total mortality by $12 \mathrm{dpf}$ (Fig 2). Lower concentrations of PEITC did not result in total mortality, but exposure to $0.1 \mu \mathrm{g} / \mathrm{L}$ PEITC raised daily mortality rates (DMR) and percentage mortality fourfold over other treatments in trials two and three (Table 1). Exposure to $0.01 \mu \mathrm{g} / \mathrm{L}$ PEITC did not raise DMR or percentage mortality rates in trials two and three, but did in trial one, which had a higher mortality rates across all treatments.

\subsection{Hatch}

Exposure to $0.1 \mu \mathrm{g} / \mathrm{L}$ PEITC significantly delayed hatching times in all trials (Table 1). In trial two, exposure to $0.1 \mu \mathrm{g} / \mathrm{L}$ PEITC significantly delayed the median hatch relative to both the control $(W=$ 49062.00, $p<0.001)$ and the $0.01 \mu \mathrm{g} / \mathrm{L}$ PEITC treatment $(W=56975.5, p<0.001)$. Similarly, in trial three there was a significant delay in median hatching for the $0.1 \mu \mathrm{g} / \mathrm{L}$ PEITC treatment over the control $(W=52196.5, p<0.001)$ and the $0.01 \mu \mathrm{g} / \mathrm{L}$ PEITC treatment $(W=16593.5, p<0.001)$. In both trials, the $0.01 \mu \mathrm{g} / \mathrm{L}$ PEITC treatment did not hatch significantly later than the controls (trial two $W=56975.5, p=0.440$; trial three $W=62775, p=0.314)$. 


\subsection{Total Length}

There was a significant difference in total length of alevins between treatments in both trials two and three (Table 1). In trial two, at $1 \mathrm{dph}$ there were significant differences between treatments $(H=$ 43.96, $d f=2, p<0.001)$. The $0.1 \mu \mathrm{g} / \mathrm{L}$ PEITC dosed alevins were significantly shorter than the solvent control $(W=516.0, p<0.001)$ and the $0.01 \mu \mathrm{g} / \mathrm{L}$ PEITC treatment $(W=544.0, p<0.001)$. Alevins exposed to $0.01 \mu \mathrm{g} / \mathrm{L}$ PEITC during embryonic development did not exhibit any significant shortening relative to the control $(W=856.0, p=0.3871)$. Similarly, in trial three at $1 \mathrm{dph}$, there were significant differences between treatments $(H=53.78, d f=2, p<0.001)$, with the $0.1 \mu \mathrm{g} / \mathrm{L}$ PEITC treated alevins significantly shorter than the pooled control $(W=546, p<0.001)$ and the $0.01 \mu \mathrm{g} / \mathrm{L}$ PEITC treatment $(W=1282.5, p<0.001)$. Once again, there was no significant difference in total length between the $0.01 \mu \mathrm{g} / \mathrm{L}$ PEITC and the pooled control $(W=1169.0, p=0.0943)$.

Alevin total length at 4dph (trial two) and $2 \mathrm{dph}$ (trial three) using a different cohort than the $1 \mathrm{dph}$ were examined. In both trials, the total length was once again significantly reduced in PEITC treated embryos. At $2 \mathrm{dph}$, there were significant differences $(H=28.72, d f=2, p<0.001)$ with the $0.1 \mu \mathrm{g} / \mathrm{L}$ significantly shorter than the solvent control $(W=356.50, p<0.001)$ and the $0.01 \mu \mathrm{g} / \mathrm{L}$ treatment $(W=$ 391.50, $p<0.001$ ). The $0.01 \mu \mathrm{g} / \mathrm{L}$ treatment was also significantly shorter than the solvent control ( $W$ $=687.00, p=0.04)$. At $4 \mathrm{dph}$ there were also significant differences between treatments $(H=45.88$, $d f=2, p<0.001)$. Here again the $0.1 \mu \mathrm{g} / \mathrm{L}$ PEITC treatment was significantly shorter than the pooled control $(W=2278, p<0.001)$ and the $0.01 \mu \mathrm{g} / \mathrm{L}$ treatment $(\mathrm{W}=82800, p<0.001)$. The $0.01 \mu \mathrm{g} / \mathrm{L}$ treated embryos were also significantly shorter than the pooled controls $(W=672, p=0.015)$.

\subsection{Yolk and Body Weights}

Trial two

The total weight of alevins collected at $1 \mathrm{dph}$ were significantly different $\left(F_{2,117}=3.41, p=0.036\right)$, with the $0.1 \mu \mathrm{g} / \mathrm{L}$ PEITC treatment significantly lighter than the pooled control $\left(F_{1,88}=6.00, p=\right.$ $0.016)$, but not the $0.01 \mu \mathrm{g} / \mathrm{L}$ PEITC treatment $\left(F_{1,58}=0.88, p=0.352\right)($ Table 1$)$. The $0.01 \mu \mathrm{g} / \mathrm{L}$ 
PEITC treatment did not differ from the pooled control $\left(F_{1,88}=2.40, p=0.125\right)$. There were significant differences in both body $\left(F_{2,117}=31.50, p<0.001\right)$ and yolk $\left(F_{2,117}=10.36, p<0.001\right)$ weights across all treatments. Alevins in the $0.01 \mu \mathrm{g} / \mathrm{L}$ PEITC treatment had significantly heavier body weight and lighter yolk weights than the controls, resulting in a lower yolk:body ratio which differed significantly from the pooled control $\left(F_{1,88}=53.38, p<0.001\right)$, and the $0.1 \mu \mathrm{g} / \mathrm{L}$ PEITC $\left(F_{1,88}\right.$ $=45.63, p<0.001)$ treatment. The $0.1 \mu \mathrm{g} / \mathrm{L}$ PEITC treatment did not differ significantly from the pooled control $\left(F_{1,88}=0.14, p=0.712\right)$.

At $4 \mathrm{dph}$, the total weight of alevins was not significantly different $\left(F_{2,93}=0.46, p=0.634\right)$. However, there were significant differences in body weight $\left(F_{2,93}=17.82, p<0.001\right)$ and yolk weight $\left(F_{2,93}=\right.$ $5.28, p=0.007)$ leading to significant differences in yolk:body ratios $\left(F_{2,93}=20.68, p<0.001\right)$. The yolk:body ratio of alevins exposed to $0.1 \mu \mathrm{g} / \mathrm{L}$ PEITC was significantly higher than the control $\left(F_{1,70}\right.$ $=33.03, p<0.001)$ and the $0.01 \mu \mathrm{g} / \mathrm{L}$ PEITC treatment $\left(F_{1,46}=28.43, p<0.001\right)$, as a consequence of this treatment having a significantly lower body weight $\left(F_{1,70}=28.46, p<0.001\right)$ and higher yolk weight $\left(F_{1,70}=10.41, p=0.002\right)$. In contrast to the alevins at $1 \mathrm{dph}$, at $4 \mathrm{dph}$ the yolk:body ratio of the $0.01 \mu \mathrm{g} / \mathrm{L}$ PEITC treatment was not significantly different to the control $\left(F_{1,70}=0.35, p=0.556\right)$, nor was the yolk weight $\left(F_{1,70}=0.65, p=0.422\right)$ or the body weight $\left(F_{1,70}=0.21, p=0.647\right)$.

\section{Trial three}

At $1 \mathrm{dph}$ the total body weight of alevins did not vary significantly $\left(F_{2,117}=0.57, p=0.564\right)($ Table 1$)$. However, there were significant differences in body weight $\left(F_{3,116}=3.94, p=0.010\right)$, yolk weight $\left(F_{2,117}=3.11, p=0.048\right)$ and yolk:body ratios $\left(F_{2,117}=8.28, p<0.001\right)$. The $0.1 \mu \mathrm{g} / \mathrm{L}$ PEITC treated fish were significantly lighter than the pooled controls $\left(F_{1,88}=8.09, p=0.006\right)$ but not significantly different to the $0.01 \mu \mathrm{g} / \mathrm{L}$ PEITC treatment $\left(F_{1,58}=0.23, p=0.636\right)$. The body weight of the 0.01 $\mu \mathrm{g} / \mathrm{L}$ PEITC treatment was between the pooled controls and the $0.1 \mu \mathrm{g} / \mathrm{L}$ PEITC treatment, and was significantly different to the pooled controls $\left(F_{1,88}=5.16, P=0.026\right)$ but not the $0.1 \mu \mathrm{g} / \mathrm{L}$ PEITC treatment $\left(F_{1,58}=0.23, p=0.636\right)$. Yolk weight of the $0.1 \mu \mathrm{g} / \mathrm{L}$ PEITC treatment was neither significantly different than the control $\left(F_{1,88}=1.70, p=0.195\right)$, nor the $0.01 \mu \mathrm{g} / \mathrm{L}$ PEITC treatment $\left(F_{1,58}=0.91, p=0.344\right)$, while the $0.01 \mu \mathrm{g} / \mathrm{L}$ PEITC treatment had significantly heavier yolk weights 
than the control group $\left(F_{1,88}=6.14, p=0.015\right)$. The yolk:body ratio of the control was significantly lower than both the $0.1 \mu \mathrm{g} / \mathrm{L}$ PEITC treatment $\left(F_{1,88}=11.07, p=0.001\right)$ and the $0.01 \mu \mathrm{g} / \mathrm{L}$ PEITC treatment $\left(F_{1,88}=12.15, p=0.001\right)$, while the two PIETC treatments did not differ significantly $\left(F_{1,58}\right.$ $=0.00, p=0.993)$.

At 2 dph in trial three, there were no significant differences in total weight $\left(F_{2,93}=0.4, p=0.959\right)$, body weight $\left(F_{2,69}=1.25, p=0.293\right)$ or yolk weight $\left(F_{2,93}=0.05, p=0.949\right)$.

\subsection{Spinal abnormalities}

Exposure to $0.1 \mu \mathrm{g} / \mathrm{L}$ PEITC during embryonic development produced the highest percentage incidence of VCD in all three of the trials (Table 2). The percentage of all hatches sampled with VCD at this highest exposure was $75 \%$ in trial one, $34.6 \%$ in trial two and $53.7 \%$ in trial three. The incidence of VCD in the controls ranged from $4.2 \%$ to $11.9 \%$. Exposure to $0.01 \mu \mathrm{g} / \mathrm{L}$ PEITC produced incidents of deformity within the range of the controls in trials two $(8.5 \%)$ and three $(9.9 \%)$, while in trial one it was $25 \%$ higher than the controls at $16.7 \%$. In trial two, rates of VCD in the controls were slightly higher than in trials one and three, and here the rates of VCD for the $0.01 \mu \mathrm{g} / \mathrm{L}$ PEITC treatment were less than $1 \%$ lower than that of the combined controls. Incidents of VCD were higher in alevins that emerged later than the median hatch time. In the $0.1 \mu \mathrm{g} / \mathrm{L}$ PEITC treatment, $52.6 \%(n=19)$ in trial two of those hatching after $41 \mathrm{dpf}$, and in trial three $82.9 \%(n=41)$ of those hatching after $42 \mathrm{dpf}$, showed VCD. The condition stump body was only observed in alevins exposed to $0.1 \mu \mathrm{g} / \mathrm{L}$ PEITC, accounting for $58.3 \%(n=24)$ of fish in trial one, $19.8 \%(n=81)$ of fish in trial two and $41.1 \%(n=95)$ of fish in trial three. Similarly to VCD, later hatches had a higher incidence of stump body than earlier hatches, accounting for $42.1 \%(n=19)$ and $69.5 \%(n=41)$ in trials two and three respectively after the median hatch date.

\subsection{Motor activity assay}

In trial two at 4 dph (Figure 3a), Repeated measures ANOVA showed significant differences between treatments $\left(F_{3,232}=9.05, p<0.001\right)$, condition (light and dark) $\left(F_{1,232}=57.41, p<0.001\right)$ and the interaction between the both factors $\left(F_{3,232}=2.65, p=0.049\right)$. Mean movement during periods of illumination was significantly greater than darkness for the water control, solvent control and the 0.01 
$\mu \mathrm{g} / \mathrm{L}$ treatment (Bonferroni post-hoc analysis; $p<0.001, p=0.001, p=0.028$ respectively). There was no significant difference in distance moved between light and dark phases for the $0.1 \mu \mathrm{g} / \mathrm{L}$ treatment $(p=1)$. Total combined movement in both light and dark periods was significantly higher in the water control than the $0.01 \mu \mathrm{g} / \mathrm{L}$ and $0.1 \mu \mathrm{g} / \mathrm{L}$ treatments ( $p=0.001$ and $p<0.001$ respectively). There was no significant difference in total movement observed between all other pairwise comparisons (water control vs. solvent control ( $p=0.069$ ); solvent control vs. $0.1 \mu \mathrm{g} / \mathrm{L}(p=0.103)$; solvent control vs. $0.01 \mu \mathrm{g} / \mathrm{L}(p=1))$.

In trial three at $2 \mathrm{dph}$ (Figure 3b), there were significant differences in mean distance moved between treatments $\left(\mathrm{F}_{3,232}=12.10, p=<0.001\right)$ and between light and dark conditions $\left(F_{1,232}=35.88, p<\right.$ $0.001)$ but not in the interaction of the two $\left(F_{3,232}=0.95, p=0.419\right)$. During illumination, movement was significantly greater in the water control $(p=0.014)$ and the solvent control $(p<0.003)$, but not significantly greater for the $0.01 \mu \mathrm{g} / \mathrm{L}$ PEITC $(p=1)$ or the $0.1 \mu \mathrm{g} / \mathrm{L}$ PEITC treatments $(p=0.195)$. For the duration of the trial (light and dark periods), the mean movement was highest in the water control, and progressively decreased with increasing dosage of PEITC. However, only the water control was significantly different to other treatments $(p<0.001)$.

\section{Discussion}

\subsection{Mortality, hatching and morphology}

Under experimental conditions, exposure to PEITC of $S$. trutta during embryogenesis led to concentration-related increases in percentage mortality and daily mortality rates. Exposure to $1 \mu \mathrm{g} / \mathrm{L}$ PEITC caused $100 \%$ embryo mortality by dose day four in all three trials. Mortality varied in the controls and sub $1 \mu \mathrm{g} / \mathrm{L}$ PEITC treatments between trials, notably the overall higher levels of mortality in trial one. This may have been a consequence of the different broodstock used. While exposure to $0.01 \mu \mathrm{g} / \mathrm{L}$ PEITC did not raise mortality rates, exposure to $0.1 \mu \mathrm{g} / \mathrm{L}$ PEITC raised it fourfold. Should such concentrations be encountered in redds, then this could impact wild populations, as even small variations in mortality rates in early life stages can cause large fluctuations in fish recruitment (Houde 1987). The DMSO solvent control did not elicit an acute toxicological response as mortality rates between the solvent and water controls varied within the natural range of 
expected mortality for S. trutta embryos (Klemetsen et al. 2003; Ojanguren and Braña 2003; RéalisDoyelle et al. 2016).

Delayed hatching was observed as a result of exposure to PEITC. S. trutta alevins incubated as embryos in the $0.1 \mu \mathrm{g} / \mathrm{L}$ PEITC treatment had significantly later median hatch times compared to the controls and the to $0.01 \mu \mathrm{g} / \mathrm{L}$ PEITC treatment. Delayed hatching is a common response to xenobiotics such as heavy metals (Jezierska et al., 2009), microcystins (Malbrouck and Kestemont 2006), xenoestrogens (Schubert et al. 2014) and environmental stress (Wu et al. 2003). In addition to delayed hatching, exposure to $0.1 \mu \mathrm{g} / \mathrm{L}$ PEITC resulted in alevins with significantly reduced total length. Alevins with small body length and delayed emergence from gravels are at higher risk of predation than larger conspecifics (Wankowski 1979; Rice et al. 1993; Taylor and McPhail 1985 Einum et al. 2014). On emergence, S. trutta must establish and defend feeding territories against conspecifics, and these territories must be acquired before the fry can locate and catch prey items effectively (Skoglund and Barlaup 2006). Aggressive competition over territory from established resident fry often displaces smaller and later emerging fry downstream (Chapman 1962; Rhodes and Quinn 1998). Fry displaced on emergence experience higher levels of mortality through predation than residents with established territories (Elliott 1986; Einum et al. 2014). In addition, smaller fry are not equipped to survive as long without food (Bagenal 1969), and can experience higher winter mortality due to energy depletion than larger conspecifics (Hunt 1969; Cargnelli and Gross 1996; Schultz et al. 1998).

Despite the shorter total length seen in the highest PEITC exposed alevins, total weights remained fairly consistent across treatments, with just the $0.1 \mu \mathrm{g} / \mathrm{L}$ PEITC treatment in trial two being significantly lower. While there were no consistent trends in yolk:body ratios between treatments at $1 \mathrm{dph}$, in the oldest cohort examined ( $4 \mathrm{dph})$ the $0.1 \mu \mathrm{g} / \mathrm{L}$ PEITC exposed animals showed signs of reduced yolk absorption having significantly reduced yolk:body weight ratio with significantly heavier yolk and lighter bodies. This might indicate that exposure to PEITC at $0.1 \mu \mathrm{g} / \mathrm{L}$ reduced the efficiency of yolk to body tissue conversion in developing alevins. In a natural scenario, this may 
delay emergence from the redd, compounding the effects of delayed hatching and putting the fry at increased risk of predation (Taylor and McPhail 1985; Rice et al. 1993)

In toxicant-stressed teleost species, the most frequent expressed developmental anomalies are skeletal deformities in the vertebral column or its predecessor, the notochord (Sfakianakis et al. 2015). Toxicants that disrupt notochord development result in permanent skeletal deformities, muscle abnormalities and neurological dysfunction. The present study found embryonic exposure of PEITC at $0.1 \mu \mathrm{g} / \mathrm{L}$ to have consistently higher levels of spinal deformities compared to the controls. In general, the $0.01 \mu \mathrm{g} / \mathrm{L}$ treatment either had no raised levels of defects over the controls, or produced an intermediate effect. Stump body is frequently observed in cultured fish where it can render them poor swimmers, less able to compete for food and more susceptible to stress (Kvellestad et al. 2000). In this study the condition only occurred in $0.1 \mu \mathrm{g} / \mathrm{L}$ PEITC exposed alevins. The levels were particularly high in later hatching individuals, and it seems most likely that the condition impaired emergence from the egg. The results presented here show a teratogenic effect of PEITC exposure, since the condition is congenital rather than genetic (Tave et al. 1982; Dunham et al. 1991).

In wild fish populations spinal deformities have been recorded in polluted waters, but are rare in relatively pristine waters (Dahlberg 1970; Boglione et al. 2001; Antunes and Lopes Da Cunha 2002; Messaoudi et al. 2009). However, a number of studies of wild fish populations indicate that the lifespan of fish displaying spinal deformities is likely to be reduced, impair swimming performance (Weis and Weis, 1976; Powell et al. 2009), and decrease an individual's ability to escape predation and forage successfully (Kroger and Guthrie 1971).

\subsection{Behaviour}

Alevins of salmonids display photonegative behaviour, with their ability to orientate away from light increasing concurrently with morphological development (Woodhead 1957). Photonegative behaviour increases up until the final stages of yolk absorption when the behaviour is reversed and they become photopositive (Woodhead, 1957; Carey and Noakes 1981; Fast and Stober 1984). Across all treatments, alevins in both the $2 \mathrm{dph}$ and 4 dph trials increased activity during exposure to light, indicating that they were photonegative. In both trials the solvent control groups exhibited 
decreased activity compared to the water controls, and in trial three significantly so. The $0.01 \% \mathrm{v} / \mathrm{v}$ DMSO used to dose treatments was below that found to cause teratogenic effects in fish in previous studies (Hallare et al. 2006; Hutchinson et al. 2006; Maes et al. 2012). However, in zebrafish (Danio rerio), Chen et al. (2011) found developmental exposure of DMSO as low as $0.01 \%$ can affect locomotor activity without causing any other observable developmental defects. Contrary to the present study, Chen et al., (2011) found embryonic exposure to $0.01,0.1$ and $1 \% \mathrm{v} / \mathrm{v}$ significantly increased distance moved by $D$. rerio relative to the water control, indicating that there may be species-specific impacts on behaviour following DMSO exposure. While the solvent control caused a reduction in overall activity levels, and the solvent is likely to have contributed to reduced activity in the PEITC treatments, only alevins exposed to $0.1 \mu \mathrm{g} / \mathrm{L}$ in trial both trials and to $0.01 \mu \mathrm{g} / \mathrm{L}$ PEITC in trial two failed to significantly increase activity levels in light. In response to light, Carey and Noakes (1981) found rainbow trout (Oncorhynchus mykiss) alevins migrate downwards into gravels. In situations where alevins become displaced from gravel, such as scouring events or superimposition of redds by later spawning salmonids, a photonegative behaviour would effectively help orientate them to the safety of the gravels (Bams 1969; Fast and Stober 1984). Should a wild population of salmonids be exposed to PEITC during embryonic development, a weakened photonegative response, as was observed in this study, may leave alevins above gravel for longer following disturbance. Such exposure may render them at greater risk of predation following displacement by water currents (Elliott 1986; Einum et al. 2014).

\subsection{Implications}

The results of the present study indicate a potential survival risk to early life stages of $S$. trutta if exposed to PEITC in wild populations. The concentrations of PEITC used were up to three orders of magnitude lower than estimates of leachate following biofumigation (Laegdsmand et al. 2007), in discharge water during harvesting of watercress (Worgan and Tyrell 2005), and from its salad wash effluent (Dixon 2010). However, these published figures must be treated with caution, being a) estimates rather than quantified levels in discharges, and b) estimates of discharges rather than concentrations encountered in salmonid redds or receiving waterbodies, where the local hydrology 
and variable rates of biodegradation would act to dilute PEITC to varying degrees (Hamilton et al. 2016). While dilution and biodegradation will almost certainly mean lower PEITC concentrations encountered by embryos in the environment than the estimates given, the relatively low concentrations that elicited significant toxicological effects remain a potential cause for concern. In the present study, PEITC dosing was halted when the first embryo hatched. However, the eleutheroembryo phase between hatching and exogenous feeding is considered the most vulnerable early life stage to toxicants (Woltering 1984; Finn 2007; Sloman and Mcneil 2012), when the chorion protecting the embryo is lost and the gills are directly exposed to waterborne contaminants (Von Westernhagen 1988). Hence, it is possible that mortality and teratogenicity is likely to occur in this sensitive life stage at PEITC concentrations below those found to cause embryotoxic responses.

The suite of teratogenic impacts on development of embryos at PEITC concentrations of $0.01 \mu \mathrm{g} / \mathrm{L}$ were less marked or absent compared to exposure to $0.1 \mu \mathrm{g} / \mathrm{L}$ PEITC. These results indicate that for developing embryos, environmental concentrations of PEITC below $0.01 \mu \mathrm{g} / \mathrm{L}$ are unlikely to produce acute toxicity or teratogenicity. However, concentrations as low as $0.01 \mu \mathrm{g} / \mathrm{L}$ may result in higher predation of alevins through altered behaviours. Moreover, as adverse effects of early life exposure to toxicants may not be manifest until adulthood in both reduced reproductive success (Coe et al. 2010) and altered behaviours (Brown et al. 2016) in adult fish, concentrations below $0.01 \mu \mathrm{g} / \mathrm{L}$ PEITC may have longer-term impacts. Ongoing exposure to environmental levels of $0.1 \mu \mathrm{g} / \mathrm{L}$ and above are liable to increase embryo mortality, delay hatching, and increase predation risk due to increased rates of morphological abnormalities and a reduced response to stimuli. Significant mortality of embryos is likely to occur if exposed to concentrations of PEITC at $1 \mu \mathrm{g} / \mathrm{L}$ or greater. These findings highlight an urgent need to accurately quantify PEITC levels in the aquatic environment emanating from watercress farms and biofumigation. In addition, there is a need for comprehensive surveys of fish population structures around discharges from watercress farms and biofumigated fields to assess whether PEITC releases are having an impact on recruitment. It is hoped these findings of acute toxicity and teratogenic impacts of exposure to low levels of PEITC will spur the development of a reliable standard methodology to test and monitor environmental levels of PEITC in the aquatic 
environment. Further, should environmental concentrations of PEITC be found to exceed the levels which cause acute toxicity and teratogenic impacts to embryos, then mitigation strategies for the treatment of effluents should be sought.

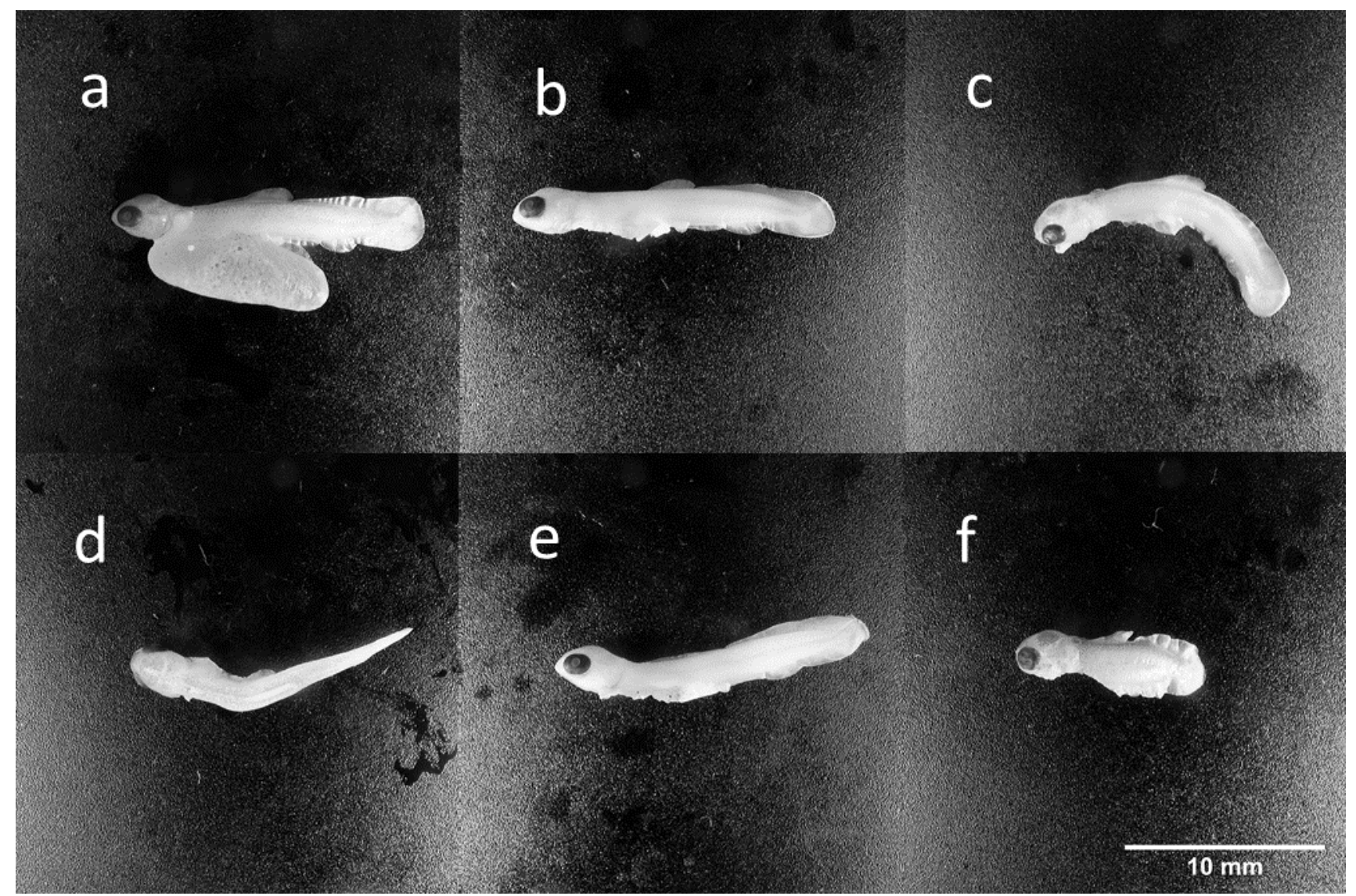

Fig 1 Salmo trutta alevin morphology, examples of a) normal alevin before removal of yolk sac; b) normal alevin after removal of yolk sac; c) lordosis; d) scoliosis; e) kyphosis and f) stump body 


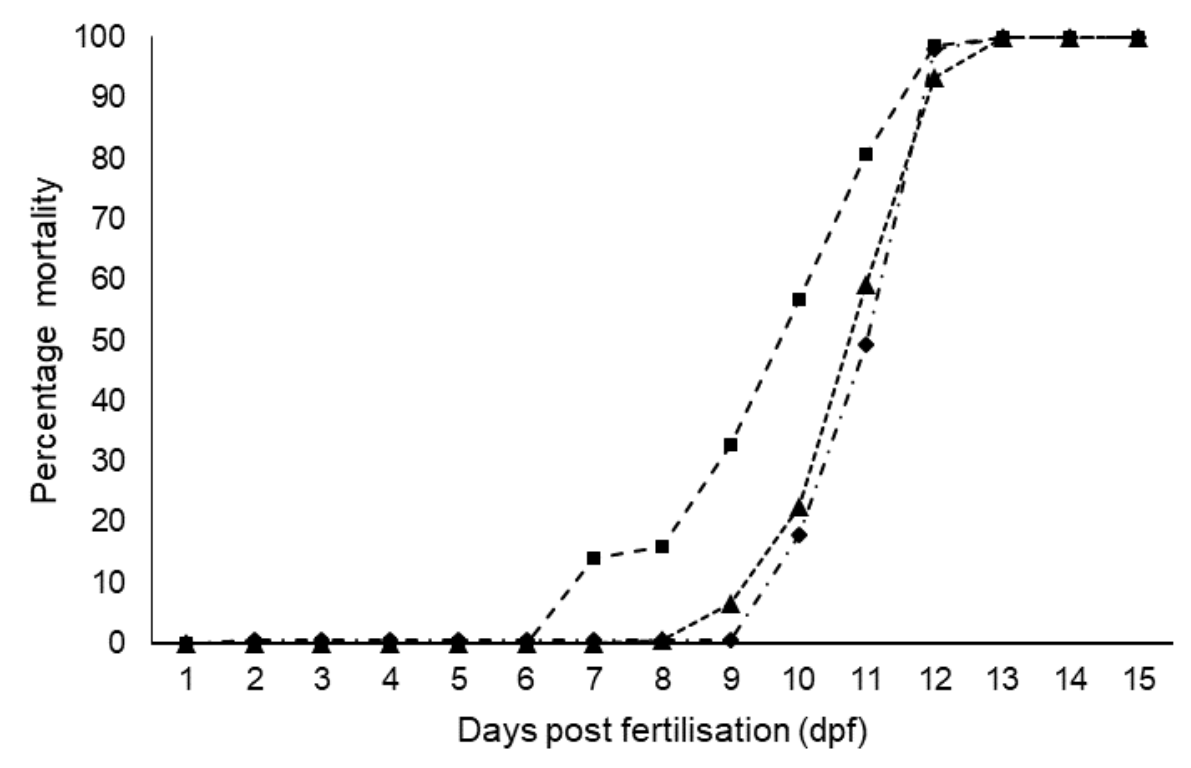

- - - trial $1 \quad---\mathbf{- - -}$ trial $2 \quad-\cdot-$ trial 3

Fig 2 Cumulative mortality (\%) of Salmo trutta embryos during exposure to 1ug/L PEITC during embryonic development. Dosing occurred on day 1, 4, 7, 10 and 13 post-fertilisation 
Table 1 Hatch and mortality, morphometrics and motor assay summary data of Salmo trutta exposed during embryonic development to $0.01,0.1$ and $1 \mu \mathrm{g} / \mathrm{L}$ PEITC and water control (WC) and solvent control (SC). Showing duration to hatch in days post fertilisation (dpf) and morphometry at 1, 2 and 4 days post hatch (dph)

\begin{tabular}{|c|c|c|c|c|c|c|c|c|c|c|c|c|c|c|c|}
\hline & \multicolumn{5}{|c|}{ Trial one } & \multicolumn{5}{|l|}{ Trial two } & \multicolumn{5}{|l|}{ Trial three } \\
\hline & WC & SC & $0.01 \mu \mathrm{g} \mathrm{L}$ & $0.1 \mu \mathrm{g} \mathrm{L}$ & $1 \mu \mathrm{g} L$ & WC & SC & $0.01 \mu \mathrm{g} \mathrm{L}$ & $0.1 \mathrm{gL} \mathrm{L}$ & $1 \mu \mathrm{g} \mathrm{L}$ & WC & SC & $0.01 \mu \mathrm{g} \mathrm{L}$ & $0.1 \mu \mathrm{g} \mathrm{L}$ & $1 \mu \mathrm{g} \mathrm{L}$ \\
\hline \multicolumn{16}{|l|}{ Mortality and hatching } \\
\hline$n$ & 150 & 150 & 150 & 100 & 150 & 145 & 142 & 143 & 143 & 150 & 150 & 150 & 149 & 150 & 150 \\
\hline Duration (dpf) & 45 & 48 & 51 & 51 & $11^{\dagger}$ & 42 & 42 & 42 & 42 & $12^{+}$ & 43 & 43 & 43 & 43 & $12+$ \\
\hline Total Mortality & 24 & 13 & 43 & 61 & 150 & 6 & 6 & 6 & 23 & 150 & 2 & 4 & 4 & 16 & 150 \\
\hline Mortality (\%) & 16.0 & 8.7 & 28.7 & 61.0 & 100.0 & 4.1 & 4.2 & 4.2 & 16.1 & 100.0 & 1.3 & 2.7 & 2.7 & 10.7 & 100.0 \\
\hline Daily Mortality Rate & 0.37 & 0.19 & 0.60 & 1.27 & 9.09 & 0.10 & 0.10 & 0.10 & 0.38 & 8.33 & 0.03 & 0.06 & 0.06 & 0.25 & 8.33 \\
\hline Mean hatch (dpf) & - & - & - & - & - & $40.48 \pm 0.64 \S^{a}$ & $40.33 \pm 0.56 \S^{a}$ & $40.34 \pm 0.56^{a}$ & $40.88 \pm 1.04^{b^{* * *}}$ & - & $41.65 \pm 0.68 \S^{a}$ & $41.72 \pm 0.65 \S^{a}$ & $41.76 \pm 0.64^{a}$ & $42.53 \pm 1.10^{0^{* * *}}$ & - \\
\hline \multicolumn{16}{|l|}{ Morphometry at $1 \mathrm{dph}$} \\
\hline$n$ & - & - & - & - & - & 30 & 30 & 30 & 30 & - & 30 & 30 & 30 & 30 & - \\
\hline Total length (mm) & - & - & - & - & - & $14.80 \pm 0.44 \ddagger$ & $15.55 \pm 0.41 \ddagger^{\mathrm{a}}$ & $15.41 \pm 0.47^{\mathrm{a}}$ & $13.76 \pm 1.56^{b^{* * *}}$ & - & $15.67 \pm 0.38 \S^{a}$ & $15.50 \pm 0.49 \S^{a}$ & $15.42 \pm 0.54^{\mathrm{a}}$ & $13.74 \pm 1.78^{b * * *}$ & - \\
\hline Total weight $(\mu \mathrm{g})$ & - & - & - & - & - & $92.13 \pm 3.85 \S^{a}$ & $93.81 \pm 3.14 \S^{a}$ & $91.74 \pm 3.43^{\mathrm{a}}$ & $90.68 \pm 5.17^{\mathrm{b}^{*}}$ & - & $72.91 \pm 3.05 \S$ & $74.10 \pm 2.95 \S$ & $74.16 \pm 3.22$ & $73.30 \pm 3.91$ & - \\
\hline Body weight $(\mu \mathrm{g})$ & - & - & - & - & - & $22.18 \pm 1.88 \ddagger$ & $23.35 \pm 1.70 \ddagger^{a^{* * *}}$ & $25.42 \pm 1.62^{\mathrm{b***}}$ & $22.04 \pm 1.74^{c^{* * *}}$ & - & $22.18 \pm 1.19 \S^{a}$ & $22.86 \pm 1.49 \S^{a}$ & $21.73 \pm 1.82^{\mathrm{ab}^{*}}$ & $21.50 \pm 1.97^{* * * *}$ & - \\
\hline Yolk weight ( $\mu \mathrm{g})$ & - & - & - & - & - & $69.95 \pm 3.37 \S^{a}$ & $70.46 \pm 3.58 \S^{a}$ & $66.32 \pm 3.35^{\mathrm{b***}}$ & $68.64 \pm 4.84^{\mathrm{ab}^{*}}$ & - & $50.73 \pm 2.66 \S^{a}$ & $51.27 \pm 2.84 \S^{a}$ & $52.43 \pm 2.27^{\mathrm{b}^{*}}$ & $51.80 \pm 2.81^{\mathrm{ab}}$ & - \\
\hline Yolk:body ratio & - & - & - & - & - & $3.17 \pm 0.30 \S^{\mathrm{a}}$ & $3.04 \pm 0.33 \S^{a}$ & $2.62 \pm 0.24^{b^{* * *}}$ & $3.12 \pm 0.34^{\mathrm{a}}$ & - & $2.30 \pm 0.16 \S^{a}$ & $2.25 \pm 0.21 \S^{a}$ & $2.43 \pm 0.21^{b^{* * *}}$ & $2.43 \pm 0.23^{b^{* * *}}$ & - \\
\hline \multicolumn{16}{|l|}{ Morphometry at $2 \mathrm{dph}$} \\
\hline$n$ & - & - & - & - & - & - & - & - & - & - & 24 & 24 & 24 & 24 & - \\
\hline Total length (mm) & - & - & - & - & - & - & - & - & - & - & $15.73 \pm 0.31 \ddagger$ & $16.07 \pm 0.42^{\mathrm{a}}$ & $15.86 \pm 0.33^{b^{*}}$ & $14.72 \pm 1.61^{* * * *}$ & - \\
\hline Total weight ( $\mu \mathrm{g})$ & - & - & - & - & - & - & - & - & - & - & $73.99 \pm 3.37 \S$ & $73.90 \pm 3.40 \S$ & $73.71 \pm 2.44$ & $73.81 \pm 4.04$ & - \\
\hline Body weight ( $\mu \mathrm{g})$ & - & - & - & - & - & - & - & - & - & - & $23.28 \pm 1.78 \neq$ & $24.75 \pm 1.60 \ddagger$ & $23.66 \pm 1.36$ & $24.00 \pm 2.35$ & - \\
\hline Yolk weight ( $\mu \mathrm{g})$ & - & - & - & - & - & - & - & - & - & - & $50.71 \pm 2.97 \S$ & $49.15 \pm 2.63 \S$ & $50.05 \pm 1.67$ & $49.81 \pm 2.87$ & - \\
\hline Yolk:body ratio & - & - & - & - & - & - & - & - & - & - & $2.19 \pm 0.21 \mp$ & $1.99 \pm 0.15 \ddagger$ & $2.12 \pm 0.12$ & $2.09 \pm 0.22$ & - \\
\hline \multicolumn{16}{|l|}{ Morphometry at 4dph } \\
\hline$n$ & - & - & - & - & - & 24 & 24 & 24 & 24 & & - & - & - & - & - \\
\hline Total length (mm) & - & - & - & - & - & $17.12 \pm 0.42 \S^{a}$ & $16.93 \pm 0.47 \S^{a}$ & $16.73 \pm 0.49^{\mathrm{b}^{*}}$ & $15.54 \pm 0.99^{c^{* * *}}$ & - & - & - & - & - & - \\
\hline Total weight $(\mu \mathrm{g})$ & - & - & - & - & - & $93.61 \pm 4.21 \S$ & $94.02 \pm 3.45 \S$ & $94.26 \pm 3.77$ & $93.23 \pm 3.49$ & - & - & - & - & - & - \\
\hline Body weight $(\mu \mathrm{g})$ & - & - & - & - & - & $33.13 \pm 2.81 \S$ & $32.30 \pm 1.98 \S$ & $32.46 \pm 1.57^{\mathrm{a}}$ & $29.49 \pm 2.36^{b^{* *}}$ & - & - & - & - & - & - \\
\hline Yolk weight ( $\mu \mathrm{g})$ & - & - & - & - & - & $60.48 \pm 3.45 \S^{a}$ & $61.72 \pm 3.61 \S^{a}$ & $61.73 \pm 3.22^{\mathrm{ab}}$ & $63.74 \pm 2.63^{\mathrm{b}^{* *}}$ & - & - & - & - & - & - \\
\hline Yolk:body ratio & - & - & - & - & - & $1.84 \pm 0.21 \S^{\mathrm{a}}$ & $1.92 \pm 0.20 \S^{\mathrm{a}}$ & $1.91 \pm 0.13^{\mathrm{a}}$ & $2.18 \pm 0.21^{b * *}$ & - & - & - & - & - & - \\
\hline \multicolumn{16}{|l|}{ Spinal abnormalites (\%) } \\
\hline$n$ & 24 & 24 & 24 & 24 & - & 73 & 59 & 59 & 81 & - & 69 & 70 & 71 & 95 & - \\
\hline Scoliosis & 0.0 & 0.0 & 0.0 & 12.5 & - & 6.8 & 10.2 & 3.4 & 16.0 & - & 1.4 & 1.4 & 8.5 & 15.8 & - \\
\hline Lordosis & 4.2 & 4.2 & 12.5 & 33.3 & - & 0.0 & 1.7 & 5.1 & 6.2 & - & 4.3 & 4.3 & 2.8 & 11.6 & - \\
\hline Kyphosis & 0.0 & 0.0 & 4.2 & 4.2 & - & 0.0 & 1.7 & 0.0 & 3.7 & - & 0.0 & 0.0 & 0.0 & 6.3 & - \\
\hline Stump body & 0.0 & 0.0 & 0.0 & 58.3 & - & 0.0 & 0.0 & 0.0 & 19.8 & - & 0.0 & 0.0 & 0.0 & 44.2 & - \\
\hline Total VCD & 4.2 & 4.2 & 16.7 & 75.0 & - & 6.8 & 11.9 & 8.5 & 36.4 & - & 4.3 & 5.7 & 9.9 & 53.7 & - \\
\hline \multicolumn{16}{|l|}{ Motor activity assay } \\
\hline$n$ & - & - & - & - & - & 24 & 24 & 24 & 24 & - & 24 & 24 & 24 & 24 & - \\
\hline Total distance moved $(\mathrm{cm})$ & - & - & - & - & - & $1.17 \pm 0.90$ & $0.66 \pm 0.69$ & $0.69 \pm 0.47$ & $0.54 \pm 0.51$ & - & $0.85 \pm 0.68$ & $0.63 \pm 0.57$ & $0.52 \pm 0.55$ & $0.44 \pm 0.45$ & - \\
\hline Distance moved in dark $(\mathrm{cm})$ & - & - & - & - & - & $0.94 \pm 0.66$ & $0.40 \pm 0.42$ & $0.57 \pm 0.40$ & $0.36 \pm 0.26$ & - & $0.55 \pm 0.46$ & $0.41 \pm 0.28$ & $0.35 \pm 0.31$ & $0.34 \pm 0.28$ & - \\
\hline Distance moved in light $(\mathrm{cm})$ & - & - & - & - & - & $1.52 \pm 1.10^{* * *}$ & $1.05 \pm 0.84^{* * *}$ & $0.86 \pm 0.52^{*}$ & $0.81 \pm 0.66$ & - & $1.31 \pm 0.71^{* *}$ & $0.97 \pm 0.71^{* * *}$ & $0.79 \pm 0.71$ & $0.59 \pm 0.60$ & - \\
\hline
\end{tabular}


Table 2 Percentage of Salmo trutta alevins displaying vertebral column disorder (VCD) and stump body following exposure to PEITC, and a water control (WC) and solvent control (SC) during embryonic development. Hatching times at days post fertilisation (dpf) was unknown in trial one, and here just the percentage of sampled alevins with spinal deformities is shown. In trials two and three, dpf was known, and here the percentage of sampled alevins displaying spinal deformities at the time of median hatch and later is shown, together with the total percentage of all sampled hatches exhibiting deformities

\begin{tabular}{|c|c|c|c|c|c|c|c|c|c|c|c|c|c|c|c|c|c|c|}
\hline \multirow{3}{*}{ VCD } & \multicolumn{2}{|c|}{ Trial one } & \multicolumn{8}{|c|}{ Trial two } & \multicolumn{8}{|c|}{ Trial three } \\
\hline & \multirow{2}{*}{\multicolumn{2}{|c|}{$\begin{array}{l}\text { hatched } \\
n\end{array}$}} & \multicolumn{8}{|c|}{ Time of hatching } & \multicolumn{8}{|c|}{ Time of hatching } \\
\hline & & & $\mathrm{n}$ & $40 d p f$ & $n$ & $41 d p f$ & $n$ & $>41 d p f$ & $n$ & all hatches & $n$ & $41 d p f$ & $n$ & $42 d p f$ & $n$ & $>42 d p f$ & $n$ & all hatches \\
\hline WC & 24 & 4.2 & 24 & 0.0 & 30 & 16.7 & 14 & 0.0 & 73 & 6.8 & 24 & 0.0 & 30 & 10.0 & 12 & 0.0 & 69 & 4.3 \\
\hline SC & 24 & 4.2 & 24 & 4.2 & 31 & 19.4 & 2 & 0.0 & 59 & 11.9 & 24 & 0.0 & 30 & 6.7 & 12 & 16.7 & 70 & 5.7 \\
\hline $0.01 \mu \mathrm{g} / \mathrm{L}$ & 24 & 16.7 & 24 & 8.3 & 30 & 10.0 & 0 & $\mathrm{n} / \mathrm{a}$ & 59 & 8.5 & 24 & 16.6 & 30 & 6.7 & 15 & 6.7 & 71 & 9.9 \\
\hline \multirow[t]{2}{*}{$0.1 \mu \mathrm{g} / \mathrm{L}$} & 24 & 75.0 & 24 & 25.0 & 31 & 35.5 & 19 & 52.6 & 81 & 34.6 & 24 & 29.2 & 30 & 33.3 & 41 & 82.9 & 95 & 53.7 \\
\hline & \multicolumn{2}{|c|}{ Trial one } & \multicolumn{8}{|c|}{ Trial two } & \multicolumn{8}{|c|}{ Trial three } \\
\hline \multirow[t]{2}{*}{ Stump body } & hat & & \multicolumn{8}{|c|}{ Time of hatching } & \multicolumn{8}{|c|}{ Time of hatching } \\
\hline & $n$ & & $\mathrm{n}$ & $40 d p f$ & $n$ & $41 d p f$ & $n$ & $>41 d p f$ & $n$ & all hatches & $n$ & $41 d p f$ & $n$ & $42 d p f$ & $n$ & $>42 d p f$ & $n$ & all hatches \\
\hline WC & 24 & 0.0 & 24 & 0.0 & 30 & 0.0 & 14 & 0.0 & 73 & 0.0 & 24 & 0.0 & 30 & 0.0 & 12 & 0.0 & 69 & 0.0 \\
\hline SC & 24 & 0.0 & 24 & 0.0 & 31 & 0.0 & 2 & 0.0 & 59 & 0.0 & 24 & 0.0 & 30 & 0.0 & 12 & 0.0 & 70 & 0.0 \\
\hline $0.01 \mu \mathrm{g} / \mathrm{L}$ & 24 & 0.0 & 24 & 0.0 & 30 & 0.0 & 0 & $\mathrm{n} / \mathrm{a}$ & 59 & 0.0 & 24 & 0.0 & 30 & 0.0 & 15 & 0.0 & 71 & 0.0 \\
\hline $0.1 \mu \mathrm{g} / \mathrm{L}$ & 24 & 58.3 & 24 & 12.5 & 31 & 22.6 & 19 & 42.1 & 81 & 19.8 & 24 & 16.6 & 30 & 23.7 & 41 & 65.9 & 95 & 41.1 \\
\hline
\end{tabular}
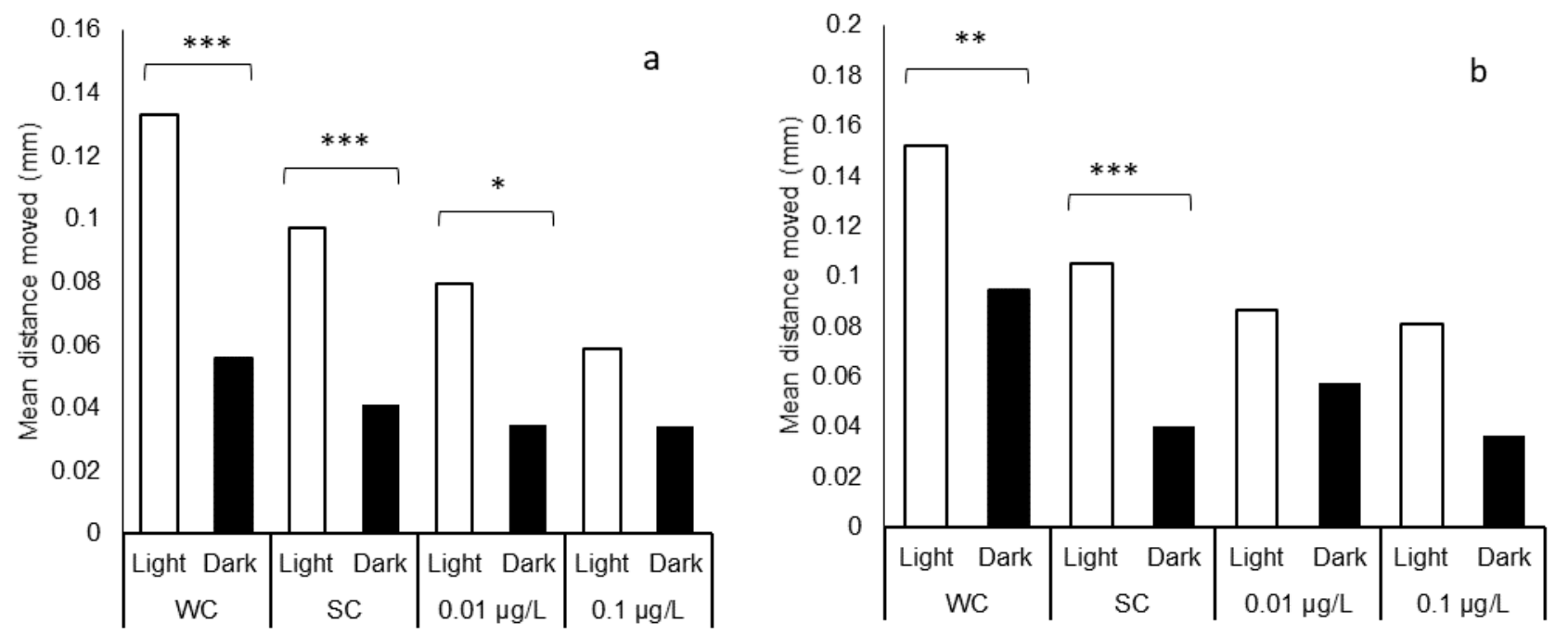

Fig 3 Effects of PEITC exposure at 0.1 and $0.01 \mu \mathrm{g} / \mathrm{L}$ and water control (WC) and DMSO solvent control (SC) during embryonic development on mean distance moved (+ SE) of Salmo trutta alevins in light and dark conditions during trial two at 4 days post hatch (a) and trial three at 2 days post hatch (b). Means generated from $10 \mathrm{~s}$ time bins during light and dark periods. Results of Repeated Measures ANOVA/Bonferroni post-hoc comparison; * $p<0.05,{ }^{* *}: p<0.01,{ }^{* * *}: p<0.001$ 


\section{Conflicts of Interest}

The authors have no conflicts of interest to declare

\section{References}

Abbaoui, B., Lucas, C. R., Riedl, K. M., Clinton, S. K., \& Mortazavi, A. (2018). Cruciferous Vegetables, Isothiocyanates, and Bladder Cancer Prevention. Molecular Nutrition \& Food Research, 62(18), 1800079. doi:10.1002/mnfr.201800079

Antunes, M., \& Lopes Da Cunha, P. (2002). Skeletal anomalies in Gobius niger (Gobiidae) from Sado estuary, Portugal. Cybium, 26(3), 179-184. http://www.scopus.com/inward/record.url?eid=2s2.0-0037201828\&partnerID=tZOtx3y1

Bagenal, T. B. (1969). Relationship between Egg Size and Fry Survival in Brown Trout Salmo trutta L. Journal of Fish Biology, 1(4), 349-353. doi:10.1111/j.1095-8649.1969.tb03882.x

Bams, R. (1969). Adaptations of sockeye salmon associated with incubation in stream gravels. In T. G. Northcote (Ed.), (Symposium., pp. 71-87). The University of British Columbia, Vancouver: Institute of Fisheries.

Boglione, C., Gagliardi, F., Scardi, M., \& Cataudella, S. (2001). Skeletal descriptors and quality assessment in larvae and post-larvae of wild-caught and hatchery-reared gilthead sea bream (Sparus aurata L. 1758). Aquaculture, 192(1), 1-22. doi:10.1016/S0044-8486(00)00446-4

Bossus, M. C., Guler, Y. Z., Short, S. J., Morrison, E. R., \& Ford, A. T. (2014). Behavioural and transcriptional changes in the amphipod Echinogammarus marinus exposed to two antidepressants, fluoxetine and sertraline. Aquatic Toxicology, 151, 46-56. doi:10.1016/j.aquatox.2013.11.025

Brown, D. R., Bailey, J. M., Oliveri, A. N., Levin, E. D., \& Di Giulio, R. T. (2016). Developmental exposure to a complex PAH mixture causes persistent behavioral effects in naive Fundulus heteroclitus (killifish) but not in a population of PAH-adapted killifish. Neurotoxicology and Teratology, 53, 55-63. doi:10.1016/j.ntt.2015.10.007 
Carey, W. E., \& Noakes, D. L. G. (1981). Development of photobehavioural responses in young rainbow trout, Salmo gairdneri Richardson. Journal of Fish Biology, 19(3), 285-296. doi:10.1111/j.1095-8649.1981.tb05832.x

Cargnelli, L. M., \& Gross, M. R. (1996). The temporal dimension in fish recruitment: birth date, body size, and size-dependent survival in a sunfish (bluegill: Lepomis macrochirus). Canadian Journal of Fisheries and Aquatic Sciences, 53(2), 360-367. doi:10.1139/cjfas-53-2-360

Chapman, D. W. (1962). Aggressive behavior in juvenile coho salmon as a cause of emigration. Journal of the Fisheries Research Board of Canada, 19(6), 1047-1080. doi:10.1139/f62-069

Chen, C.-W., \& Ho, C.-T. (1998). Thermal degradation of allyl isothiocyanate in aqueous solution. Journal of Agricultural and Food Chemistry, 46(1), 220-223 EP-. http://pubs.acs.org/doi/abs/10.1021/jf990082e. Accessed 5 December 2016

Chen, T.-H., Wang, Y.-H., \& Wu, Y.-H. (2011). Developmental exposures to ethanol or dimethylsulfoxide at low concentrations alter locomotor activity in larval zebrafish: Implications for behavioral toxicity bioassays. Aquatic Toxicology, 102(3-4), 162-166.

Coe, T. S., Söffker, M. K., Filby, A. L., Hodgson, D., \& Tyler, C. R. (2010). Impacts of early life exposure to estrogen on subsequent breeding behavior and reproductive success in Zebrafish. Environmental Science and Technology, 44(16), 6481-6487. doi:10.1021/es101185b

Cox, J. (2009). Watercress growing and its environmental impacts on chalk rivers in England (NECR 027). www.naturalengland.org.uk (pp. 1-52)

Crisp, D. T. (1993). The environmental requirements of salmon and trout in fresh water. Freshwater Forum, 3(3), 176-202. http://aquaticcommons.org/4542/. Accessed 29 July 2017

Dahlberg, M. D. (1970). Frequencies of Abnormalities in Georgia Estuarine Fishes. Transactions of the American Fisheries Society, 99(1), 95-97. doi:10.1577/15488659(1970)99<95:FOAIGE $>2.0 . C O ; 2$

Dinkova-Kostova, A. T., \& Kostov, R. V. (2012). Glucosinolates and isothiocyanates in health and 
disease. Trends in Molecular Medicine. doi:10.1016/j.molmed.2012.04.003

Dixon, M. J. (2010). The Sustainable Use of Water to Mitigate the Impact of Watercress Farms on Chalk Streams in Southern England. University of Southampton. Retrieved from https://eprints.soton.ac.uk/195397/

Dixon, M. J., \& Shaw, P. J. (2011). Watercress and water quality: The effect of phenethyl isothiocyanate on the mating behaviour of Gammarus pulex. International Journal of Zoology. doi:10.1155/2011/328749

Doheny-Adams, T., Lilley, C. J., Barker, A., Ellis, S., Wade, R., Atkinson, H. J., et al. (2018). Constant Isothiocyanate-Release Potentials across Biofumigant Seeding Rates. Journal of Agricultural and Food Chemistry, 66(20), 5108-5116. doi:10.1021/acs.jafc.7b04610

Dunham, R. A., Smitherman, R. O., \& Bondari, K. (1991). Lack of Inheritance of Stumpbody and Taillessness in Channel Catfish. The Progressive Fish-Culturist, 53(2), 101-105. doi:10.1577/1548-8640(1991)053<0101:LOIOSA >2.3.CO;2

Einum, S., Fleming, I. A., Einum, S., \& Fleming, I. A. N. A. (2014). Selection against Late Emergence and Small Offspring in Atlantic Salmon (Salmo salar). Evolution, 54(2), 628-639.

Elliott, J. M. (1986). Spatial Distribution and Behavioural Movements of Migratory Trout Salmo trutta in a Lake District Stream. Journal of Animal Ecology, 55(3), 907-922. doi:10.2307/4424

Elliott, J. M. (1989). Wild brown trout Salmo trutta: an important national and international resource. Freshwater Biology, 21(1), 1-5. doi:10.1111/j.1365-2427.1989.tb01343.x

Elliott, J. M., \& Hurley, M. A. (1998). Predicting fluctuations in the size of newly emerged sea-trout fry in a Lake District stream. Journal of Fish Biology, 53(5), 1120-1133. doi:10.1111/j.10958649.1998.tb00468.x

Fast, D. E., \& Stober, Q. J. J. (1984). Intragravel behavior of salmonid alevins in response to environmental changes. Fisheries Research Institute. https://digital.lib.washington.edu/researchworks/bitstream/handle/1773/4040/8414.pdf?sequence 
$=1$. Accessed 8 September 2017

Fenwick, G. R., Heaney, R. K., Mullin, W. J., \& VanEtten, C. H. (1983). Glucosinolates and their breakdown products in food and food plants. $C R C$ Critical Reviews in Food Science and Nutrition, 18(2), 123-201. doi:10.1080/10408398209527361

Finn, R. N. (2007). The physiology and toxicology of Salmonid eggs and larvae in relation to water quality criteria in relation to water quality criteria. Aquatic Toxicology, 81(81), 337-354. doi:10.1016/j.aquatox.2006.12.021

Gimsing, A. L., \& Kirkegaard, J. A. (2009). Glucosinolates and biofumigation: Fate of glucosinolates and their hydrolysis products in soil. Phytochemistry Reviews. doi:10.1007/s11101-008-9105-5

Green, J., \& Wheeler, J. R. (2013). The use of carrier solvents in regulatory aquatic toxicology testing: Practical, statistical and regulatory considerations. Aquatic Toxicology, 144-145, 242249. doi:10.1016/J.AQUATOX.2013.10.004

Halkier, B. A., \& Gershenzon, J. (2006). Biology and Biochemistry of Glucosinolates. Annu. Rev. Plant Biol, 57, 303-33. doi:10.1146/

Hallare, A., Nagel, K., Köhler, H. R., \& Triebskorn, R. (2006). Comparative embryotoxicity and proteotoxicity of three carrier solvents to zebrafish (Danio rerio) embryos. Ecotoxicology and Environmental Safety, 63(3), 378-388. doi:10.1016/j.ecoenv.2005.07.006

Hamilton, P. B., Cowx, I. G., Oleksiak, M. F., Griffiths, A. M., Grahn, M., Stevens, J. R., et al. (2016). Population-level consequences for wild fish exposed to sublethal concentrations of chemicals - a critical review. Fish and Fisheries. doi:10.1111/faf.12125

Houde, E. (1987). Fish Early Life Dynamics and Recruitment Variability. In American Fisheries Society Symposium (p. 2: 17-29).

Hua, J., Vijver, M. G., Richardson, M. K., Ahmad, F., \& Peijnenburg, W. J. G. M. (2014). Particlespecific toxic effects of differently shaped zinc oxide nanoparticles to zebrafish embryos ( Danio rerio ). Environmental Toxicology and Chemistry, 33(12), 2859-2868. doi:10.1002/etc.2758 
Hunt, R. L. (1969). Overwinter Survival of Wild Fingerling Brook Trout in Lawrence Creek, Wisconsin. Journal of the Fisheries Research Board of Canada, 26(6), 1473-1483. doi:10.1139/f69-138

Hutchinson, T. H., Shillabeer, N., Winter, M. J., \& Pickford, D. B. (2006). Acute and chronic effects of carrier solvents in aquatic organisms: A critical review. Aquatic Toxicology. doi:10.1016/j.aquatox.2005.09.008

Jezierska, B., Ługowska, K., \& Witeska, M. (2009). The effects of heavy metals on embryonic development of fish (a review). Fish Physiology and Biochemistry, 35(4), 625-640. http://www.ncbi.nlm.nih.gov/pubmed/19020985

Ji, Y., Kuo, Y., \& Morris, M. E. E. (2005). Pharmacokinetics of Dietary Phenethyl Isothiocyanate in Rats. Pharmaceutical Research, 22(10), 1658-1666. doi:10.1007/s11095-005-7097-z

Kerfoot, W. C., Newman, R. M., \& Hanscom, Z. (1998). Snail reaction to watercress leaf tissues: Reinterpretation of a mutualistic "alarm" hypothesis. Freshwater Biology, 40(2), 201-213. doi:10.1046/j.1365-2427.1998.00334.x

Klemetsen, A., Amundsen, P.-A., Dempson, J. B., Jonsson, B., Jonsson, N., O’Connell, M. F., \& Mortensen, E. (2003). Atlantic salmon Salmo salar L., brown trout Salmo trutta L. and Arctic charr Salvelinus alpinus (L.): a review of aspects of their life histories. Ecology of Freshwater Fish, 12(1), 1-59. doi:10.1034/j.1600-0633.2003.00010.x

Kristensen, P. (1994). Sensitivity of embryos and larvae in relation to other stages in the life cycle of fish: a literature review. In Sublethal and Chronic Effects of Pollutants on Freshwater Fish (pp. 155-166). Oxford: Fishing News Books.

Kroger, R. L., \& Guthrie, J. F. (1971). Incidence of crooked vertebral columns in Juvenile Atlantic menhaden, Brevoortia tyrannus. Chesapeake Science, 12(4), 276-278. doi:10.2307/1350917

Kvellestad, A., Høie, S., Thorud, K., ... B. T.-D. of A., \& 2000, U. (2000). Platyspondyly and shortness of vertebral column in farmed Atlantic salmon Salmo salar in Norway-description and 
interpretation of pathologic changes. int-res.com, 39, 97-108. https://www.intres.com/abstracts/dao/v39/n2/p97-108/. Accessed 1 November 2018

Laegdsmand, M., Gimsing, A. L., Strobel, B. W., Sørensen, J. C., Jacobsen, O. H., \& Hansen, H. C. B. (2007). Leaching of isothiocyanates through intact soil following simulated biofumigation. Plant and Soil, 291(1-2), 81-92. doi:10.1007/s11104-006-9176-2

Maes, J., Verlooy, L., Buenafe, O. E., de Witte, P. A. M., Esguerra, C. V., \& Crawford, A. D. (2012). Evaluation of 14 Organic Solvents and Carriers for Screening Applications in Zebrafish Embryos and Larvae. PLoS ONE, 7(10). doi:10.1371/journal.pone.0043850

Mainstone, C. P. (1999). Chalk rivers: Nature conservation and management. Water Reseach Centre. doi:10.1017/CBO9781107415324.004

Malbrouck, C., \& Kestemont, P. (2006). Effects of microcystins on fish. Environmental Toxicology and Chemistry, 25(1), 72-86. doi:10.1897/05-029R.1

Mann, R., Blackburn, J., \& Beaumont, W. (1989). The ecology of brown trout Salmo trutta in English chalk streams. Freshwater Biology, 21(1), 57-70.

Matthiessen, J. N., \& Kirkegaard, J. A. (2006). Biofumigation and enhaces biodegradation: opportunity and challenge in soilborne pest and disease managemente. Plant Sciences, 25(3), 235-265. http://www.tandfonline.com/doi/abs/10.1080/07352680600611543. Accessed 5 December 2016

Messaoudi, I., Deli, T., Kessabi, K., Barhoumi, S., Kerkeni, A., \& Saïd, K. (2009). Association of spinal deformities with heavy metal bioaccumulation in natural populations of grass goby, Zosterisessor ophiocephalus Pallas, 1811 from the Gulf of Gabès (Tunisia). Environmental Monitoring and Assessment, 156(1-4). doi:10.1007/s10661-008-0504-2

Newman, R. M., Kerfoot, W. C., \& Hanscom, Z. (1990). Watercress and amphipods Potential chemical defense in a spring stream macrophyte. Journal of Chemical Ecology, 16(1), 245-259. doi:10.1007/BF01021282 
Newman, R. M., Kerfoot, W. C., \& Hanscom, Z. (1996). Watercress allelochemical defends highnitrogen foliage against consumption: Effects on freshwater invertebrate herbivores. Ecology, 77(8), 2312-2323. doi:10.2307/2265733

Ntalli, N., Caboni, P., \& Ntalli Pierluigi Caboni, N. (2017). A review of isothiocyanates biofumigation activity on plant parasitic nematodes. Phytochemistry Reviews, 1-8. doi:10.1007/s11101-017-9491-7

OECD. (1992). OECD Guidline for testing chemicals Zahn-Wellens/EMPA1 Test 302B. www.oecd.org

Ojanguren, A. F., \& Braña, F. (2003). Thermal dependence of embryonic growth and development in brown trout. Journal of Fish Biology, 62(3), 580-590.

Pan, J. H., Abernathy, B., Kim, Y. J., Lee, J. H., Kim, J. H., Shin, E. C., \& Kim, J. K. (2018). Cruciferous vegetables and colorectal cancer prevention through microRNA regulation: A review. Critical Reviews in Food Science and Nutrition, 58(12), 2026-2038. doi:10.1080/10408398.2017.1300134

Petersen, J., Belz, R., Walker, F., \& Hurle, K. (2001). Weed suppression by release of isothiocyanates from turnip-rape mulch. In Agronomy Journal (Vol. 93, pp. 37-43). doi:10.2134/agronj2001.93137x

Powell, M. D., Jones, M. A., \& Lijalad, M. (2009). Effects of skeletal deformities on swimming performance and recovery from exhaustive exercise in triploid Atlantic salmon. Diseases of Aquatic Organisms, 85(1), 59-66. doi:10.3354/dao02056

Power, M. (1994). Quantitative Ecology and the brown trout. Transactions of the American Fisheries Society, 123(6), 1006-1008. doi:10.1577/1548-8659-123.6.1006

Réalis-Doyelle, E., Pasquet, A., De Charleroy, D., Fontaine, P., \& Teletchea, F. (2016). Strong effects of temperature on the early life stages of a cold stenothermal fish species, brown trout (Salmo trutta L.). PLoS ONE, 11(5), e0155487. doi:10.1371/journal.pone.0155487 
Rhodes, J. S., \& Quinn, T. P. (1998). Factors affecting the outcome of territorial contests between hatchery and naturally reared coho salmon parr in the laboratory. Journal of Fish Biology, 53(6), 1220-1230. doi:10.1006/jfbi.1998.0787

Rice, J. A., Miller, T. J., Rose, K. A., Crowder, L. B., Marschall, E. A., Trebitz, A. S., \& DeAngelis, D. L. (1993). Growth Rate Variation and Larval Survival: Inferences from an Individual-Based Size-Dependent Predation Model. Canadian Journal of Fisheries and Aquatic Sciences, 50(1), 133-142. doi:10.1139/f93-015

Roddie, B., Kedwards, T., \& Crane, M. (1992). Potential impact of watercress farm discharges on the freshwater amphipod, Gammarus pulex L. Bulletin of Environmental Contamination and Toxicology, 48(1), 63-69. doi:10.1007/BF00197484

Rodrigues, L., Silva, I., Poejo, J., Serra, A. T., Matias, A. A., Simplício, A. L., et al. (2016). Recovery of antioxidant and antiproliferative compounds from watercress using pressurized fluid extraction. RSC Advances, 6(37), 30905-30918. doi:10.1039/C5RA28068K

Rumberger, A., \& Marschner, P. (2003). 2-Phenylethyl isothiocyanate concentration and microbial community composition in the rhizosphere of canola. Soil Biology and Biochemistry, 35(3), 445-452. http://www.sciencedirect.com/science/article/pii/S0038071702002961. Accessed 5 December 2016

Schubert, S., Peter, A., Schönenberger, R., Suter, M. J. F., Segner, H., \& Burkhardt-Holm, P. (2014). Transient exposure to environmental estrogen affects embryonic development of brown trout (Salmo trutta fario). Aquatic Toxicology, 157, 141-149. doi:10.1016/j.aquatox.2014.10.007

Schultz, E. T., Conover, D. O., \& Ehtisham, A. (1998). The dead of winter: size-dependent variation and genetic differences in seasonal mortality among Atlantic silverside (Atherinidae: Menidia menidia) from different latitudes. Canadian Journal of Fisheries and Aquatic Sciences, 55(5), 1149-1157. doi:10.1139/cjfas-55-5-1149

Sfakianakis, D. G., Renieri, E., Kentouri, M., \& Tsatsakis, A. M. (2015). Effect of heavy metals on 
fish larvae deformities: A review. Environmental Research. doi:10.1016/j.envres.2014.12.014

Shelton, A. L. (2005). Within-plant variation in glucosinolate concentrations of Raphanus sativus across multiple scales. Journal of Chemical Ecology, 31(8), 1711-1732. doi:10.1007/s10886005-5922-9

Skoglund, H., \& Barlaup, B. T. (2006). Feeding pattern and diet of first feeding brown trout fry under natural conditions. Journal of Fish Biology, 68(2), 507-521. doi:10.1111/j.00221112.2006.00938.x

Sloman, K. A., \& Mcneil, P. L. (2012). Using physiology and behaviour to understand the responses of fish early life stages to toxicants. Journal of Fish Biology. doi:10.1111/j.10958649.2012.03435.x

Smith, B. J., \& Kirkegaard, J. A. (2002). In vitro inhibition of soil microorganisms by 2-phenylethyl isothiocyanate. Plant Pathology, 51(5), 585-593. doi:10.1046/j.1365-3059.2002.00744.x

Strähle, U., Geisler, R., Greiner, P., Hollert, H., Rastegar, S., Schumacher, A., et al. (2012). Zebrafish embryos as an alternative to animal experiments-A commentary on the definition of the onset of protected life stages in animal welfare regulations. Reproductive Toxicology, 33(2), 128-132. doi:10.1016/J.REPROTOX.2011.06.121

Tave, D., Bartels, J. E., \& Smitherman, R. O. (1982). Stumpbody Sarotherodon aureus $($ Steindachner $)(=$ Tilapia aurea) and tail-less S. niloticus $($ L.)(= T. niloticd): two vertebral anomalies and their effects on body length. Journal of Fish Diseases, 5(6), 487-494.

Taylor, E. B., \& McPhail, J. D. (1985). Burst swimming and size-related predation of newly emerged coho salmon Oncorhynchus kisutch. Transactions of the American Fisheries Society, 8487(114), 546-551. doi:10.1577/1548-8659(1985)114

Traka, M., \& Mithen, R. (2009). Glucosinolates, isothiocyanates and human health. Phytochemistry Reviews. doi:10.1007/s11101-008-9103-7

Von Westernhagen, H. (1988). Sublethal effects of pollutants on fish eggs and larvae. Fish physiology 
(Vol. 11). Elsevier BV. doi:10.1016/s1546-5098(08)60201-0

Wankowski, J. W. J. (1979). Spatial distribution and feeding in atlantic salmon, Salmo salar L. juveniles. Journal of Fish Biology, 30(3), 787-247. doi:10.1111/j.1095-8649.1979.tb03515.x

Weis, P., \& Weis, J. S. (1976). Abnormal locomotion associated with skeletal malformations in the sheepshead minnow, Cyprinodon variegatus, exposed to malathion. Environmental Research, 12(2), 196-200. doi:10.1016/0013-9351(76)90024-4

Woltering, D. M. (1984). The growth response in fish chronic and early life stage toxicity tests: A critical review. Aquatic Toxicology, 5(1), 1-21. doi:10.1016/0166-445X(84)90028-6

Woodhead, P. M. J. (1957). Reaction of Salmonid larvae to light. Journal of Experimental Biology, 34(1954), 402-416.

Worgan, A. D., \& Tyrell, R. (2005). Monitoring behavioural responses of Gammarus pulex to watercress oils.. Centre for Ecology and Hydrology, CO2786NEW

Wu, R. S., Zhou, B. S., Randall, D. J., Woo, N. Y., \& Lam, P. K. (2003). Aquatic hypoxia is an endocrine disruptor and impairs fish reproduction. Environmental Science and Technology, 37(6), 1137-1141. doi:10.1021/es02 